\title{
TESES E DISSERIACÕES EM ANTROPOLOGIA DEFENDIDAS NA UNIVERSIDADE FEDERAL DO RIO GRANDE DO SUL NO PERIODO DE JANEIRO A MARCO DE 2002
}

\author{
Dissertacõos:
}

\section{ALMEIDA JÚNIOR, Francisco de Assis de}

Orientador: Ari Pedro Oro

"Aprontando filhos-de-santo": um estudo antropológico sobre a transmissão/reinvenção da tradição em uma rede de "casas de batuque" em POA.

A transmissão/reinvenção da tradição batuqueira dá-se através da construção da pessoa dos praticantes dessa religião. Tal processo caracterizase por uma intervenção profunda na corporalidade dos sujeitos, expressa através do aprendizado de um conjunto de práticas rituais - compreendidas unicamente como os fundamentos do batuque - que incorporam a visão de mundo e os valores essenciais dessa religiosidade tradicional: a hierarquia e a reciprocidade. $\mathrm{O}$ aprendizado desses atos pode ser percebido como uma forma especial de projeto, em sua dimensão individual - definida pela conquista de uma posição na hierarquia ritual batuqueira - e familiar - expressa no engajamento em profundidade em uma família-de-santo e sua descendência religiosa. Assim, a construção da pessoa batuqueira consiste num processo de singularização num sistema holista, baseado na performance pública de atos rituais eficazes.

\section{FRANCA, Maria Cristina Caminha de Castilhos}

\section{Orientadora: Cornélia Eckert}

A cidade narrada na memória dos velhos habitantes de Teutônia (RS): estudo etnográfico de memória intrageracional e compartilhada sobre as experiências transmitidas na relação entre avós e netos.

Estudo de antropologia sobre a memória intrageracional e compartilhada na cidade de Teutônia. Trata-se de uma pesquisa etnográfica (2000-2001) realizada junto a antigos moradores, descendentes de imigrantes alemães que colonizaram essa região, hoje uma próspera cidade localizada no Vale do 
Taquari (RS). Investiga-se, a partir de narrativas biográficas, as tradições transmitidas de geração a geração na vida cotidiana, pelo qual os avós socializam seus filhos e netos à tradição de seu ethos de pertencimento, enraizado em uma trajetória de descendência alemã, bem como ressituam esses valores no tempo presente, reordenando-os sob a luz das novas condições socioculturais advindas das transformações decorrentes da modernidade.

\section{GRÉGIS, Cristiano}

Orientadora: Daniela Riva Knauth

Fissura da rua: corpo e ritual do uso de droga injetável entre meninos de rua.

O presente estudo etnográfico aborda o cotidiano de meninos de rua em um território da cidade de Porto Alegre e busca interpretar os danos decorrentes do consumo inadequado de drogas e a epidemia de HIV/AIDS entre os sujeitos. Os dados são fruto de observação participante, com uma regularidade quase que semanal, de 35 sujeitos encontrados na rua em períodos alternados, de outubro de 2000 a julho de 2001. O estudo parte da construção do problema meninos de rua como uma imagem ambivalente que será montada nas relações do sujeito com os outros. Em seguida, são descritas as táticas de obtenção de recursos e montagem de mocós, destacando a precariedade desse território e a itinerância dos sujeitos. Esse território e a imagem de meninos de rua inscrevem nos corpos dos sujeitos os códigos do abandono e da doença, em particular dos danos recorrentes do consumo inadequado de drogas e da infecção pelo HIV/AIDS. Os resultados apontam para um cotidiano que traz muitos danos à saúde dos sujeitos, danos que são intensificados como códigos de rua através do ritual do uso de drogas.

\section{RODRIGUES, Gilse Elisa}

Orientador: Carlos Alberto Steil

Negociando crenças: um estudo antropológico sobre conversão religiosa em uma penitenciária feminina.

Essa dissertação tem como tema a conversão religiosa das mulheres em situação prisional, atentando para as possibilidades de reorganização de suas trajetórias através da religiosidade. 
Os estudo realizado na Penitenciária Feminina Madre Pelletier, em Porto Alegre, objetiva a compreensão da especificidade do mercado religioso que se constitui na referida instituição, tendo em vista o processo de secularização na qual ela está inserida. Destaca-se também os recursos disponibilizados pelos diferentes sistemas religiosos para as narrativas construídas pelas detentas.

Torna-se importante, nesse sentido, analisar as negociações que essas mulheres estabelecem na interação com os agentes religiosos no espaço prisional, bem como os limites e possibilidades para uma flexibilização e autonomização dos sistemas de crenças que estão sendo reinterpretados nesse processo.

\section{ROSÁRIO, Valéria Aydos}

Orientador: Carlos Alberto Steil

Vidas marcadas: experiências de tortura nas trajetórias de presos políticos no período da Ditadura Militar em Porto Alegre, Rio Grande do Sul.

Os acontecimentos políticos que nortearam a vida pública do Brasil durante o regime militar (1964-1985), particularmente nos anos 1960 e 1970, contaram com a repressão, implantada e institucionalizada pela ditadura militar. Dentre as diversas formas de repressão sofridas por aqueles que se opuseram ao regime, vamos tratar como objeto de estudo as experiências de tortura. Após os chamados anos de chumbo, começa um processo de abertura política e redemocratização do país que, hoje, conta com iniciativas de reparo dos danos causados pelo regime e, também, de resgate da memória e reconhecimento daqueles que lutaram contra a ditadura. Tendo essas iniciativas como pano de fundo deste trabalho e compreendendo que são espaços privilegiados da construção da memória coletiva de um grupo de expresos e torturados políticos do Rio Grande do Sul, buscamos compreender os sentidos e significados atribuídos por esses sujeitos às suas experiências de tortura, assim como o papel desta na construção de suas identidades individuais e coletivas. 


\section{SANTOS, Simone Ritta dos}

Orientadora: Claudia Lee Williams Fonseca

Mulher de preso, mulher de respeito: uma etnografia sobre as relações familiares entre as mulheres e seus homens presos no sistema prisional do Rio Grande do Sul.

O presente estudo etnográfico foi realizado junto a um grupo de mulheres, mães, irmãs e esposas, que mantinham relações de parentesco com homens que cumpriam pena no regime fechado do Complexo Penitenciário de Charqueadas, Rio Grande do Sul. O estudo propôs-se a analisar a importância das mulheres para a articulação de redes formadas pelos seus familiares, amigos e vizinhos, juntamente com as instituições do sistema prisional, que permitem a sobrevivência física e moral dos parentes, bem como as estratégias utilizadas pelas mesmas para enfrentar os estigmas decorrentes da prisão do homem que recaem sobre os presidiários e sobre elas. Observou-se os discursos e práticas que apontam para a manutenção dos laços e a importância dos homens no âmbito familiar apesar de sua prisão. $\mathrm{Na}$ lógica que orienta as relações sociais entre as mulheres, destaca-se o valor da família e o princípio de reciprocidade. 